\title{
Is Acetylsalicylic Acid a Safe and Potentially Useful Choice for Adult Patients with COVID-19?
}

\author{
Vanessa Bianconi ${ }^{1} \cdot$ Francesco Violi $^{2}$. Francesca Fallarino ${ }^{3} \cdot$ Pasquale Pignatelli $^{2} \cdot$ Amirhossein Sahebkar $^{4,5,6}$. $^{2}$ \\ Matteo Pirro'
}

Published online: 23 July 2020

(c) The Author(s) 2020

\begin{abstract}
Severe Acute Respiratory Syndrome-Coronavirus-2 is responsible for the current pandemic that has led to more than 10 million confirmed cases of Coronavirus Disease-19 (COVID-19) and over 500,000 deaths worldwide (4 July 2020). Virus-mediated injury to multiple organs, mainly the respiratory tract, activation of immune response with the release of pro-inflammatory cytokines, and overactivation of the coagulation cascade and platelet aggregation leading to micro- and macrovascular thrombosis are the main pathological features of COVID-19. Empirical multidrug therapeutic approaches to treat COVID-19 are currently used with extremely uncertain outcomes, and many others are being tested in clinical trials. Acetylsalicylic acid (ASA) has both anti-inflammatory and antithrombotic effects. In addition, a significant ASA-mediated antiviral activity against DNA and RNA viruses, including different human coronaviruses, has been documented. The use of ASA in patients with different types of infections has been associated with reduced thrombo-inflammation and lower rates of clinical complications and in-hospital mortality. However, safety issues related both to the risk of bleeding and to that of developing rare but serious liver and brain damage mostly among children (i.e., Reye's syndrome) should be considered. Hence, whether ASA might be a safe and reasonable therapeutic candidate to be tested in clinical trials involving adults with COVID-19 deserves further attention. In this review we provide a critical appraisal of current evidence on the antiinflammatory, antithrombotic, and antiviral effects of ASA, from both a pre-clinical and a clinical perspective. In addition, the potential benefits and risks of use of ASA have been put in the context of the adult-restricted COVID-19 population.
\end{abstract}

\section{Introduction}

The recent pandemic of Severe Acute Respiratory Syndrome-Coronavirus-2 (SARS-CoV-2) disease, termed

Matteo Pirro

matteo.pirro@unipg.it

1 Unit of Internal Medicine, Department of Medicine, Hospital "Santa Maria Della Misericordia", University of Perugia, Piazzale Menghini, 1, 06129 Perugia, Italy

2 Department of Clinical, Internal Medicine and Cardiovascular Sciences, Sapienza University of Rome, Rome, Italy

3 Unit of Pharmacology, Department of Experimental Medicine, University of Perugia, Perugia, Italy

4 Halal Research Center of IRI, FDA, Tehran, Iran

5 Biotechnology Research Center, Pharmaceutical Technology Institute, Mashhad University of Medical Sciences, Mashhad, Iran

6 Neurogenic Inflammation Research Center, Mashhad University of Medical Sciences, Mashhad, Iran

\section{Key Points}

Specific treatments with undisputable safety and efficacy are still required for controlling viral replication, inflammation, and thrombotic risk during COVID-19.

Acetylsalicylic acid has anti-inflammatory and antithrombotic effects, as well as some antiviral activity against DNA and RNA viruses.

Whether acetylsalicylic acid might be a safe and reasonable therapeutic candidate to be tested in clinical trials involving adults with COVID-19 deserves further attention.

COVID-19, has affected more than 10 million people and caused over 500,000 deaths worldwide (4 July 2020) [1]. In patients with COVID-19, the infectious virus has been documented in the respiratory tract, where active viral replication and diffuse alveolar damage occur [2, 3]. Fever, respiratory symptoms and myalgia are the most frequent 
clinical features of COVID-19 [4]. Importantly, lung and systemic inflammation are responsible for much of COVID19 's severity [5], which may ultimately cause severe respiratory failure, multi-organ dysfunction, and death [6].

Thrombotic complications frequently occur in patients with COVID-19 [7, 8]. In this regard, thrombocytopenia, elevated fibrin degradation products, prothrombin time (PT), and activated partial thromboplastin time (aPTT) prolongation, venous thromboembolism and disseminated intravascular coagulation (DIC) have been reported in COVID-19 patients [7-9]. Importantly, a hypercoagulable state during viral infections can result in an increased risk of thrombotic events [10]. More specifically, viral infections are commonly accompanied by platelet activation and aggregation, resulting in platelet consumption and thrombocytopenia [11]. Furthermore, over-expression of thromboxane synthase (TBXAS) and Toll-like receptor 9 (TLR9) genes, which are strictly implicated in platelet aggregation [12,13], has been documented in vitro during SARS-CoV infection [14]. Due to the similarities between the different coronavirus $(\mathrm{CoV})$ mediated diseases, these results might also suggest the presence of increased platelet activity and aggregability in patients with COVID-19. This conclusion is partially supported by the evidence of platelet activation in patients with community-acquired pneumonia [15].

Based on these premises, a detrimental interaction between SARS-CoV-2 replication into the respiratory tract, alveolar epithelium injury, lung and systemic inflammation, and platelet hyper-aggregability should be suspected and concomitantly managed in the most severe forms of COVID-19.

Acetylsalicylic acid (ASA), marketed in 1899 under the registered trademark of Aspirin, has anti-inflammatory, analgesic, antipyretic, and antithrombotic effects [16]. These effects are obtained because ASA inhibits prostaglandin (PG) and thromboxane synthesis by irreversible inactivation of both cyclo-oxygenase-1 (COX-1) and cyclo-oxygenase-2 (COX-2). Additional mechanisms of ASA-induced effects include, among the others, modulation of nuclear factor kappa-light-chain-enhancer of activated B cells (NF- $\mathrm{KB}$ ) pathway, down-regulation of inducible nitric oxide synthase (iNOS), oxidative phosphorylation uncoupling, and increased permeability in mitochondria [17]. Along with its well-established role in reducing inflammation [16] and platelet aggregation [18], antiviral effects have also been proposed for ASA both against DNA and RNA viruses [19]. Among the latter effects, D,L-lysine acetylsalicylate (i.e., a lysine-salt formulation of ASA) reduced RNA synthesis and replication of the human CoV-229E and Middle East Respiratory Syndrome (MERS)-CoV titer in cultured infected cells [20].

The aim of this review was to critically appraise current evidence on the potential benefits and risks of ASA, putting them in the context of the adult-restricted COVID-19 population.

\section{Clinical Implications for SARS-CoV-2 Infection}

There is compelling evidence suggesting that SARS-CoV-2 infection may be asymptomatic, pauci-symptomatic, or symptomatic [21]. Although COVID-19 is generally a mild disease in children and infants, in some cases it may manifest in younger age groups as a multisystem inflammatory syndrome with Kawasaki's disease-like features (e.g., fever, mucocutaneous manifestations, cervical lymphadenopathy, conjunctival injection, cardiac involvement) or even multiorgan failure [22]. In adulthood, the clinical spectrum of symptomatic SARS-CoV-2 infection is extremely heterogeneous, ranging from mild to severe and potentially life-threatening manifestations [21]. The most common initial symptoms, including fever, dry cough, myalgia, or fatigue, are generally mild and non-specific [21,23]. Less commonly, COVID-19 clinical onset is characterized by nausea, vomiting, diarrhea, abdominal pain, and anosmia with or without dysgeusia [24, 25]. A delayed progression to dyspnea with respiratory failure requiring hospital admission has been reported to occur in more than half of cases [21, 26]. According to different reports, hypertension, cardiovascular diseases, and diabetes mellitus are the three most prevalent underlying co-morbidities among COVID-19 patients undergoing hospitalization [27]. Upon hospitalization, intensive care unit (ICU) admission may be required in about $20 \%$ of cases due to either acute respiratory distress syndrome (ARDS) or other severe complications, including DIC and other thrombotic disorders [23]. Although early reports have described ARDS and multi-organ failure as the main in-hospital complications of COVID-19, more recent studies have shown that venous thromboembolism and arterial thrombosis have a high incidence rate and a detrimental impact on prognosis of hospitalized COVID-19 patients $[7,28]$. In addition, evidence of myocardial injury, likely due to a combination of a direct virus-mediated and an indirect immune-mediated injury of cardiomyocytes, has been frequently found in patients with COVID-19 [29, 30]. In a Chinese cohort of 416 hospitalized patients with COVID-19, individuals with myocardial injury were more likely to necessitate ventilation and die because of COVID-19 complications [31]. Also, in a Chinese case series of 72,314 COVID-19 patients, the overall case fatality rate was $2.3 \%$, but it reached $6 \%, 7.3 \%$, and $10.5 \%$ in patients with hypertension, diabetes, or underlying cardiovascular disease [32]. Moreover, mortality exceeded $50 \%$ in a retrospective case series of 187 COVID-19 patients with myocardial injury [33].

Clinical and laboratory features of hospitalized COVID19 patients are predictive of COVID-19 progression towards 
its most severe clinical manifestations and fatal outcome [34-38]. These features include: older age, underlying comorbidities, higher Sequential Organ Failure Assessment (SOFA) scores (indicative of organ dysfunction), abnormal hemostasis parameters (i.e., increased levels of D-dimer and fibrin degradation products, and decreased platelet counts) and increased biomarkers of cardiac injury and dysfunction (i.e., N-terminal pro-brain natriuretic peptide and troponin) [34-38]. Thus, in a retrospective case series of 187 COVID19 patients, troponin $\mathrm{T}$ elevation was significantly associated with a greater probability of developing ARDS, arrythmias, and other complications as compared with troponin $\mathrm{T}$ within the normal range [33].

The search of possible therapeutic strategies against SARS-CoV-2 is rapidly proceeding. To date, a number of potential target therapies have been proposed, including angiotensin-converting enzyme 2 (ACE2) inhibitors [39]. Indeed, ACE2 is a crucial molecule in SARS-CoV-2 infection as viral particle entry into host cell is mediated by $S$ protein interaction with ACE2 [39]. However, given the current lack of approved specific therapies, COVID-19 treatment is currently based on supportive care, including symptomatic therapies for mild clinical manifestations and respiratory support [40]. Several drugs approved for other indications as well as multiple investigational agents and potential therapies may provide new opportunities for treating patients infected with SARS-CoV-2. Therapeutic alternatives include specific (remdesivir seems the most promising compound) and non-specific antiviral agents, immune-modulatory agents, other anti-infective agents repurposed to treat COVID-19, and drugs acting on host cell receptors [39-42]. Future clinical studies are needed to highlight the possible pharmacological interactions of some investigational drugs used in the therapy of COVID19-positive cancer patients with antineoplastic drugs [43]. Moreover, the search for potential vaccines for COVID-19 is also rapidly progressing.

\section{Coronavirus Infections and Thrombosis}

An increased thrombotic risk has been observed in both SARS-CoV-1 and MERS-CoV, as confirmed in in vitro, experimental, and clinical studies. Over-expression of a significant number of genes involved in the upregulation of the coagulation cascade (e.g., fibrinogen, factors II, III, VII, $\mathrm{X}, \mathrm{XI}, \mathrm{XII}$, serine proteinase inhibitors [SERPINs]) $[14,44]$ and platelet aggregation (e.g., TBXAS, TLR9) [14] has been decribed in SARS-CoV-1-infected peripheral blood mononuclear cells and human hepatoma cells. Also, an excess of micro-vascular thrombi in the lung tissue of MERS-CoVinfected mice transgenic for human dipeptidyl peptidase 4 (DPP4) has been observed [45]. Along with these changes, alterations of laboratory markers of increased thrombotic risk have been described in patients with SARS-CoV-1 and MERS-CoV. In this regard, thrombocytopenia, increased D-dimer, and prolonged PT and aPTT have been sparsely reported in SARS-CoV-1 and MERS-CoV infections [8]. Overall, based on some case reports, the above reported hematologic manifestations of both SARS-CoV-1 and MERS-CoV infections translated into an increased risk of vein and arterial thrombosis and DIC [46, 47].

Laboratory findings in patients with SARS-CoV-2 infection are not dissimilar from those in SARS-CoV-1 and MERS-CoV infections, with relevant changes in blood coagulation parameters indicating an increased thrombotic risk [9, 48, 49] (Fig. 1). Importantly, thrombocytopenia and elevation of plasma D-dimer levels have been found to be much more evident in patients with the most severe forms of COVID-19 [4]. In addition, poor prognosis was observed among COVID-19 patients with higher D-dimer and prolonged PT [50]. From a clinical perspective, increased prevalence of DIC [51] and other vein and arterial thrombotic (e.g., small pulmonary arterioles) complications have been recorded in COVID-19 patients, with the highest prevalence among critically ill patients $[7,52,53]$. In addition, the presence of antiphospholipid antibodies (e.g., anticardiolipin IgA, anti- $\beta 2$-glycoprotein I IgA and IgG) [54], which may contribute to an increased risk of both venous and arterial thrombosis, has been described in the serum of COVID-19 patients [55, 56]. Noteworthy, evidence of cardiac injury has been observed in a retrospective case series of 187 patients with COVID-19 [33], the latter being a significant negative prognostic factor in this population [31]. Direct viral myocardial injury, systemic overactivation of the inflammation cascade, as well as virus-induced atherosclerotic plaque destabilization and micro- and macro-vascular thrombosis have been proposed as possible mechanisms leading to cardiovascular manifestations of COVID-19 [57]. In addition, several viral infections may start a hyper-inflammatory

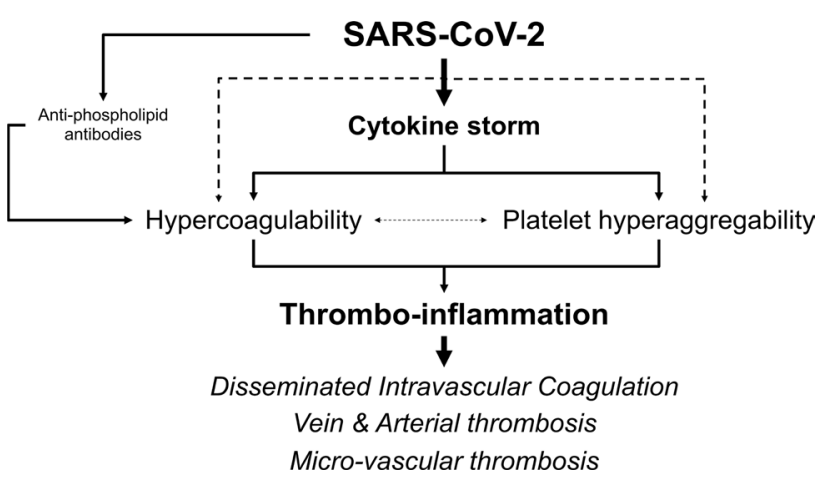

Fig. 1 Proposed mechanisms for the increased thrombotic risk related to SARS-CoV-2 infection. SARS-CoV-2 Severe Acute Respiratory Syndrome-Coronavirus-2 
Table 1 Clinical studies investigating the effects of ASA in COVID-19 according to clinicaltrials.gov

\begin{tabular}{|c|c|c|c|c|c|c|}
\hline Study type & Study identifier & $\begin{array}{l}\text { Number of } \\
\text { participant }\end{array}$ & $\begin{array}{l}\text { ASA treatment (dose and } \\
\text { duration) }\end{array}$ & Primary outcome(s) & Study phase & Status \\
\hline Interventional & NCT04365309 & 128 & ASA $100 \mathrm{mg}$ daily & $\begin{array}{l}\text { Clinical recovery time } \\
\text { The time of SARS-CoV-2 } \\
\text { overcasting }\end{array}$ & $\begin{array}{l}\text { Phase } 2 \\
\text { Phase } 3\end{array}$ & Enrolling by invitation \\
\hline Interventional & NCT04363840 & 1080 & $\begin{array}{l}\text { ASA } 81 \mathrm{mg} \text { daily for } \\
14 \text { days }\end{array}$ & Hospitalization & Phase 2 & Not yet recruiting \\
\hline Interventional & NCT04410328 & 132 & $\begin{array}{l}\text { ASA } 25 \mathrm{mg} \text { two times daily } \\
\text { for } 2 \text { weeks }\end{array}$ & $\begin{array}{l}\text { Change in composite } \\
\text { COVID ordinal scale at } \\
\text { day } 15\end{array}$ & Phase 3 & Not yet recruiting \\
\hline Interventional & NCT04343001 & 10,000 & $\begin{array}{l}\text { ASA } 150 \text { mg daily until } \\
\text { death, discharge or } \\
28 \text { days after randomisa- } \\
\text { tion, whichever occurs } \\
\text { first }\end{array}$ & Death & Phase 3 & Not yet recruiting \\
\hline Interventional & NCT04324463 & 4000 & $\begin{array}{l}\text { ASA } 75-100 \mathrm{mg} \text { once daily } \\
\text { for } 28 \text { days }\end{array}$ & $\begin{array}{l}\text { Outpatient trial: compos- } \\
\text { ite of hospitalization or } \\
\text { death } \\
\text { Inpatient trial: invasive } \\
\text { mechanical ventilation } \\
\text { or death }\end{array}$ & Phase 3 & Recruiting \\
\hline Interventional & NCT04368377 & 5 & $\begin{array}{l}\text { ASA } 250 \mathrm{mg} \text { IV before } \\
\text { starting tirofiban fol- } \\
\text { lowed by } 75 \mathrm{mg} \text { daily for } \\
30 \text { days }\end{array}$ & $\begin{array}{l}\text { Change in } \mathrm{P} / \mathrm{F} \text { ratio } \\
\mathrm{PaO}_{2} \text { difference } \\
\mathrm{A}-\mathrm{a} \mathrm{O}_{2} \text { difference }\end{array}$ & Phase 2 & Completed \\
\hline Interventional & NCT04333407 & 3170 & ASA $75 \mathrm{mg}$ daily & $\begin{array}{l}\text { All-cause mortality at } \\
30 \text { days after admission }\end{array}$ & Not applicable & Recruiting \\
\hline Observational & NCT04390126 & 1200 & ASA any dose & $\begin{array}{l}\% \text { adherence to each phar- } \\
\text { macological class } \\
\text { Number of occurrence of } \\
\text { medical events at } 1 \text { year }\end{array}$ & Not applicable & Active not recruiting \\
\hline
\end{tabular}

cytokine response, leading to platelet aggregation and microand macrovascular thrombosis (i.e., a condition called thrombo-inflammation) [58]. Hence, drugs aimed at controlling all these important sequelae of COVID-19, including accelerated thrombo-inflammation, are eagerly anticipated. In this regard, and more specifically in the context of COVID-19, the role of ASA is unknown and results from ongoing clinical studies are awaited (Table 1). Some conflicting evidence of an anti-inflammatory effect of heparin has been proposed [59]. Currently, the association between the use of low molecular-weight heparin and short-term survival has also been examined in a retrospective analysis of 449 patients with severe COVID-19 [60]. This study showed some evidence of protection from heparin use against 28-day COVID-19 mortality among severe COVID-19 patients (i.e., with either high sepsis-induced coagulopathy score or plasma D-dimer levels) [60]. It is important to emphasize the extreme importance of risk stratification for venous thromboemolism in order to ensure the most appropriate protection from increased thrombotic risk in this specific population [61].

\section{Acetylsalicylic Acid as an Anti-Inflammatory Drug}

ASA exerts its anti-inflammatory effects mostly as a nonselective inhibitor of cyclo-oxygenase (COX-1 and COX-2) enzymes, which are involved in the production of important mediators, including PGs and thromboxane A2 (TXA2), collectively called prostanoids $[16,18]$. The enzyme COX-1 is constitutively expressed in several tissues and regulates basal levels of PGs, involved in the control of platelet activation and in protection of the gastrointestinal tract [62]. In contrast to COX-1, COX-2 is inducible by inflammatory stimuli, hormones, and growth factors, also representing an important source of prostanoid formation during infections, injuries, and cancer [63].

Through acetylation of specific serine residues in the COX-1 (e.g., Ser 530) or COX-2 (e.g., Ser 516) isoenzymes, ASA permanently blocks prostanoid biosynthesis, particularly the prostanoid precursors PGG2 and PGH2, blunting a variety of pro-inflammatory responses [64]. Importantly, acetylation reactions induced by ASA lead to irreversible COX inhibition,thus, new COXs must be synthesized before 
more prostanoids can be produced [64]. Additionally, proteomic studies have reported that ASA can increase acetylation of histone proteins, thus resulting in the regulation of gene expression [65]. Better understanding of the ASAinduced acetylome might provide a novel interpretation of the anti-inflammatory effects of ASA and possibly of the additional functions ascribed to this drug, such as antiviral and antiplatelet effects. Although acetylation of COX enzymes is believed to be the primary mechanism for the anti-inflammatory effects of ASA, additional actions have been described for explaining the ability of ASA to suppress inflammation, including: (1) suppression of the prototypical proinflammatory signaling pathway NF- $\mathrm{KB}$ [66], (2) induction of heme oxygenase (HO) expression [67], and (3) acetylation of iNOS, resulting in the release of nitric oxide [68].

The potent anti-inflammatory effects of ASA have been exploited in clinical practice. At intermediate-to-high doses (650 mg to $4 \mathrm{~g} /$ day), ASA is able to irreversibly inhibit both COX-1 and COX-2, and at these doses ASA has been used for treating severe inflammatory disorders (e.g., rheumatic fever, Kawasaki disease, adult-onset Still's disease, and recurrent pericarditis) [69-74]. Significant improvement of some inflammation-related symptoms (e.g., fever, joint symptoms) and reductions of plasma levels of inflammation markers (e.g., white blood cell count, erythrocyte sedimentation rate, and C-reactive protein) have been obtained with the use of intermediate-to-high doses of ASA in all the aforementioned conditions [69-74]. In addition, a single high dose of ASA has improved symptoms related to both the common cold and flu, including fever, myalgias, headache, and sore throat $[75$, 76]. Importantly, overactivation of COXs [77], NF- $\mathrm{kB}$, and systemic cytokine responses [5, 20], along with occurrence of inflammation-related symptoms [4], are all typical hallmarks of viral infections,most of these conditions are also present in the course of COVID-19 [4 5, 20].

\section{Acetylsalicylic Acid as an Anti-Thrombotic Drug}

Low doses of ASA (e.g., 75-100 mg/day) are sufficient to irreversibly acetylate Ser 530 of COX-1, thus preferentially inhibiting platelet generation of TXA2, a potent vasoconstrictor and stimulator of platelet reactivity [78]. TXA2 inhibition by ASA results in a significant antithrombotic effect [79]. However, it is important to emphasize that the production of additional prostanoids (e.g., PGI2) by cells other than platelets (e.g., endothelial cells, arterial smooth muscle cells) can be reduced by ASA via COX-1 and COX-2 inhibition, depending on individual susceptibility, COX metabolism in different cell types, ASA doses, and additional factors [79]. In this respect, higher doses of ASA can reduce production of PGI2, a prostanoid opposing to the function of TXA2, thus potentially being less efficacious in terms of antithrombotic effects as compared to lower doses of ASA [80, 81]. However, with respect to PGI2, there is solid evidence that when ASA is used at lower doses, TXA2 inhibition greatly overcomes PGI2 inhibition, resulting in an overall antithrombotic effect $[81,82]$.

In order to obtain a significant inhibition of platelet activity and aggregation, a high level of COX-1 inhibition is necessary [82], this result can be obtained rapidly by using higher ASA doses (i.e., $\geq 300 \mathrm{mg}$ daily), and in the long term by using lower doses (i.e., $75-100 \mathrm{mg}$ daily) [83]. The efficacy of low doses of ASA as an antiplatelet agent has been documented in several randomized controlled trials, with evidence of non-superiority for higher doses as compared to lower doses in terms of antithrombotic efficacy [84]. Based on this evidence and on the results of additional randomized clinical trials, low doses of ASA are currently used for inhibiting platelet aggregation and preventing ischemic arterial events (e.g., myocardial infarction, stroke) in patients at higher thrombotic risk [85]. In addition, due to its antiplatelet effects, ASA at low doses is currently recommended for preventing thrombotic manifestations in pregnant women with antiphospholipid antibody syndrome, mechanical heart valves, or at intermediate-to-high risk of pre-eclampsia [86, 87].

In addition to its ability to prevent arterial thromboembolic events, there is some evidence that ASA may also reduce venous thromboembolism. In this regard, the pooled results of the Warfarin and Aspirin (WARFASA) and the Aspirin to Prevent Recurrent Venous Thromboembolism (ASPIRE) trials showed that in patients with a first unprovoked venous thromboembolism, after warfarin was discontinued, ASA reduced the risk of thrombotic event recurrence by $32 \%$ [88]. Mechanisms alternative to COX inhibition have been proposed to explain ASA-mediated antithrombotic effects, including the ability of ASA to cause acetylation of proteins involved in the coagulation cascade (e.g., fibrinogen), thus promoting fibrinolysis [89]. A recent metaanalysis of 13 randomized clinical trials showed that the efficacy of ASA for venous thromboembolism prophylaxis in patients undergoing total hip replacement or total knee replacement was not different from that of other anticoagulants [90]. Despite these intriguing results, the central role of the non-vitamin $\mathrm{K}$ antagonist oral anticoagulants in the prevention of recurrent venous thromboembolism must be emphasized [91, 92].

Irrespective of the relative superiority of different drug regimens in preventing venous thromboembolism, a large body of evidence supports an overall antithrombotic action of ASA that might be exploited in those conditions (e.g., infections) in which additional effects of ASA (e.g., antiinflammatory, antiviral) may be required. In this regard, there is some preliminary experimental and clinical evidence 
suggesting that ASA may serve as a potential preventive/ therapeutic strategy against infection-induced coagulopathy and DIC. Indeed, it has been demonstrated that ASA can inhibit intravascular coagulation during Staphylococcus aureus-induced sepsis in mice by reducing platelet activation and intravascular thrombin activity [93]. In addition, in a retrospective study including 390 septic shock patients from intensive care units (ICUs) antiplatelet therapy prior to hospital admission was associated with a decreased risk of overt DIC [94].

\section{Acetylsalicylic Acid as an Antiviral Drug}

The antiviral effects of salicylic acid, the principal metabolite of ASA, have already been described in plants. Salicylic acid, either produced by plants or applied to them, can induce resistance to viral infections; through this and other immune-modulating functions, salicylic acid is currently considered a plant protector from viruses and other kind of biotic and abiotic stresses [95].

In humans, the antiviral action of ASA has been extensively documented against both DNA and RNA viruses (Fig. 2). ASA reduced cytomegalovirus-induced reactive oxygen species production and $\mathrm{NF}-\mathrm{\kappa B}$ activation, thus resulting in the inhibition of cytomegalovirus replication in smooth muscle cells [96]. Also, high doses of ASA have been shown to be able to reduce varicellazoster virus replication in a partially reversible manner [97, 98], with ASA concentration and duration of exposure

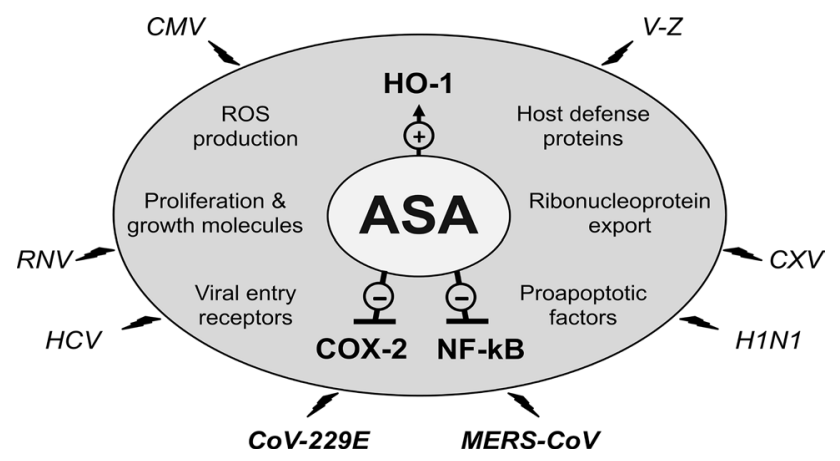

Fig. 2 Hypothetical mechanisms explaining the antiviral effects of ASA. In the grey circle are included: three main antiviral pathways modulated by ASA, including $\mathrm{COX}-2$, NF-kB, and $\mathrm{HO}-1$, and the proposed mechanisms mediating the antiviral effects of ASA. The external area includes the viruses whose replication is inhibithed by ASA: DNA viruses (CMV, V-Z) and RNA viruses (RNV, CXV, HCV, H1N1, CoV-229E, MERS-CoV). ASA acetylsalicylic acid, CoV-229E coronavirus-229E, $C O X-2$ cyclo-oxygenase-2, $C M V$ cytomegalovirus, $C X V$ coxackie virus, $H C V$ hepatitis $\mathrm{C}$ virus, $H O-1$ heme-oxygenase- 1 , HIN1 influenza virus, MERS-CoV Middle East Respiratory Syndrome-Coronavirus; $N F-k B$ nuclear factor kappa beta, $R O S$ reactive oxygen species, $R N V$ rhinovirus, $V-Z$ varicella-zoster virus of infected cells to ASA influencing reversibility [97]. In the setting of RNA viruses, ASA has been demonstrated to stimulate the over-expression of several proteins (e.g., ubiquitin-protein ligase E6A, adenylosuccinate lyase, and nibrin) that are responsible for the inhibition of hepatitis C virus (HCV) replication [99]. The inhibitory activity of ASA on HCV has been found to be mediated in part by COX-2 inhibition [100]. ASA has also been shown to enhance the proteasomal degradation of claudin-1, which serves as a $\mathrm{HCV}$ receptor, thereby reducing the entry of virus particles [101]. There is also evidence suggesting that ASA can down-regulate the promoter activity of iNOS in HCV-infected cells by reducing its affinity to CCAAT/ enhancer-binding protein-beta (C/EBP- $\beta)$, thereby inhibiting iNOS expression and HCV-RNA replication [102]. Another study showed that ASA could reduce the pathogenic effects of HCV through the down-regulation of cellular oxidative stress and the enhancement of the expression and activity of $\mathrm{Cu} / \mathrm{Zn}$ superoxide dismutase (SOD1) in infected cells [103]. Additionally, ASA showed a significant and dose-dependent antiviral activity against several other RNA viruses, including influenza A H1N1 virus, human rhinoviruses, and coxsackie virus subtype A9, this effect was observed with non-cytotoxic doses of ASA [19]. It is noteworthy that the beneficial effects of ASA against influenza virus infection have been in part attributed to ASA-mediated inhibition of PGE2 activity in macrophages and subsequent upregulation of interferon type I (IFN-1) production, leading to restricted viral replication and promoting T-cell-mediated immune response [104].

Importantly, ASA-induced overactivation of HO-1 may result in the degradation of heme, which plays a role as a pro-inflammatory mediator $[67,105]$. This anti-inflammatory mechanism of action of ASA is important in the light of two main findings: (1) the reduced lung inflammation and mortality in mice over-expressing HO-1 that are subsequently infected with influenza virus [106], (2) the decreased HO-1 expression and/or activity due to human polymorphisms of the $\mathrm{HO}-1$ gene have been associated with poor outcomes in different states of overactivation of the inflammation cascade [107]. Furthermore, nontoxic concentrations of D,L-lysine acetylsalicylate, the water-soluble salt of ASA and lysine, reduced the titer, viral RNA synthesis, and protein accumulation, as well as the replication of human CoV-229E in vitro [20]. In the same experimental conditions, D,L-lysine acetylsalicylate reduced MERS-CoV titer in Huh7-infected cells [20].

The above-mentioned antiviral effects of ASA were related in most cases to the inhibition of the virus-induced $\mathrm{NF}-\kappa \mathrm{B}$ pathway $[20,108]$. However, NF- $\kappa \mathrm{B}$-independent pathways have also been reported to be modulated by ASA during inhibition of viral activity [109]. For instance, Liao et al. showed NF- $\kappa \mathrm{B}-$ and COX-independent antiviral 
effects of ASA against flavivirus infection and suggested that this inhibitory effect could be mediated by p38 MAP kinase activation [109].

The issue regarding the ability of ASA to exert an antiviral activity partly by inhibiting NF- $\mathrm{kB}$ is of extreme importance in the light of the dual and intricate role of NF- $\mathrm{KB}$ as a regulator of the antiviral response. On the one hand, viruses inhibit the NF- $\mathrm{KB}$ pathway by encoding several NF$\kappa \mathrm{B}$ inhibitors and interfering with receptors and adaptor proteins related to the NF- $\mathrm{KB}$ pathway [110], these actions are believed to represent just one of the several mechanisms adopted by different viruses to escape host immunity [110]. On the other hand, pro-viral effects of NF- $\mathrm{KB}$ activation have been described as well. Thus, for instance, a negative inhibitor of NF- $\mathrm{BB}$ kinase $\beta$ (IKK $\beta$ ) mutation may result in impaired NF- $\kappa B$ signaling pathway and reduced viral replication [111]. Many additional examples of the pro-viral effects resulting from NF- $\kappa B$ activation have been also reported [112]. For instance, human CoV-229E-mediated activation of NF- $\mathrm{KB}$ has been demonstrated to be crucial for viral propagation in the early phase of infection [20].

All the above-reported effects of ASA on viral infection and propagation, and the related proposed mechanisms to explain such an effect, were derived from in vitro and experimental research. Whether similar effects might be extended to adult humans is a matter of discussion. In this regard, the use of ASA at over-the-counter doses in adult patients with flu and the common cold is relatively common and effective in relieving symptoms of acute upper respiratory tract viral infections like fever, myalgias, headache, and sore throat [75, 76]. However, it is likely that the anti-inflammatory activity of ASA, instead of antiviral activity, may be responsible for the rapid symptom relief following a single dose of ASA. Clinical studies are necessary to test whether a course of ASA therapy may improve symptoms and also exert a significant antiviral effect.

\section{Clinical Applications of Acetylsalicylic Acid in Infectious Diseases}

The multifaceted pharmacological effects of ASA, involving the modulation of immune-inflammation pathways, thrombosis, and viral infectivity, have been exploited as potential clinical applications in different infectious diseases.

During severe sepsis and viral infections, overactivation of the inflammation cascade, platelet hyper-reactivity, platelet-leukocyte interaction, and other detrimental molecular events occur; these phenomena may lead to systemic and pulmonary microvascular thrombosis and intravascular coagulation, which in turn increase the risk of ARDS, multiorgan failure, and death [113]. Also, ischemic cardiovascular events may complicate the early and late course of severe infections [114]. Thus, ASA, as an effective drug for the prevention of ischemic cardiovascular events [85] might be particularly useful in patients with infectious diseases.

A meta-analysis of three observational studies in mixed critically ill patients found a beneficial effect of ASA on the incidence of ARDS (odds ratio (OR) 0.59, 95\% confidence interval (CI) 0.36-0.98) [115]. A number of clinical studies in patients affected by diseases of different degrees of clinical severity (e.g., critically ill, admitted to ICUs, with sepsis, severe sepsis, community-acquired pneumonia) showed that the use of ASA was associated with lower mortality [116, 117]. These beneficial effects of ASA have been confirmed by an individual patient data meta-analysis of published observational cohort data showing a reduced sepsis-related mortality in patients taking ASA prior to the onset of sepsis [118]. A more recent meta-analysis of ten cohort studies enrolling 689,897 patients with sepsis revealed that ASA, administered either before or after sepsis, reduced ICU or hospital mortality [119]. Altogether, these findings might support the clinical usefulness of ASA in improving overall survival in patients with sepsis and, more generally, in critically ill patients.

Modulation of thrombo-inflammation has been suggested as the mechanism underlying the beneficial effects of ASA during infections [120]. However, additional clinical benefits of ASA in the setting of sepsis have been described. In a randomized, double-blind, placebo-controlled study ASA was able to partially reverse endotoxin tolerance in healthy subjects challenged intravenously with endotoxin [121]. Also, in a randomized, double-blind, placebo-controlled study enrolling 30 healthy volunteers, endotoxin-induced platelet plug formation was attenuated by ASA, thus further supporting a possible antithrombotic action of ASA in septic patients [122].

In the setting of infections from viral pathogens, ASA has also shown interesting results, albeit the level of evidence in this setting being less marked than in sepsis. In this regard, it has been found that persistent platelet activation intervenes in inflammatory, thrombotic, and virologic responses in human immunodeficiency virus (HIV) infection [123]. Thus, results of a case-control study showing the ability of ASA to attenuate platelet aggregation, T-cell and monocyte activation, and enhance leukocyte responses to toll-like receptor stimulation in virologically suppressed HIV-infected subjects on antiretroviral therapy are particularly valuable [124]. Importantly, the antiplatelet effects of ASA have also been observed in a randomized, placebo-controlled, crossover study enrolling $40 \mathrm{HIV}$-infected subjects treated with abacavir-related platelet hyper-reactivity [125]. It must be reported that in a randomized controlled trial of 121 virologically suppressed subjects living with HIV, 12-week use of ASA did not affect markers of immune activation [126]. Conversely, a significant reduction of plasma 
monocyte chemoattractant protein-1 levels and mucosal HIV target CCR5+ CD4+ cells has been obtained following 6-week ASA treatment in a randomized clinical trial enrolling 76 HIV seronegative women [127]. Furthermore, in a phase 2 proof-of-concept study, aerosolized D,L-lysineacetylsalicylate glycine, which showed antiviral activity against human CoV-229E and MERS-CoV in vitro [20], was also effective in reducing the time to symptom alleviation in hospitalized patients with influenza [128]. Similarly, in a randomized, placebo-controlled study, ASA significantly reduced symptoms of upper respiratory tract infections of suspected viral origin (i.e., fever, headache, myalgias, general discomfort) compared with placebo [75].

Altogether, these results in human infections, along with those obtained in the pre-clinical setting, may support the utility of ASA in mitigating the thrombo-inflammationrelated complications associated with infections and possibly COVID- 19.

\section{Potential Side Effects of Acetylsalicylic Acid}

Concern over the use of ASA are mostly related to side effects occurring in four main situations: (1) long-term course of therapy with intermediate-to-high doses in rheumatic-immune disorders; (2) long-term use of low doses for the prevention of ischemic cardiovascular diseases; (3) use of low doses for the prevention of thrombotic complications during pregnancy; (4) short-term use of high doses in children with a viral infection.

Irrespective of its effectiveness, intermediate-to-high doses of ASA have been used for the treatment of different rheumatic-immune disorders, including rheumatic fever, Kawasaki disease, adult-onset Still's disease, and recurrent pericarditis [69-73]. In some of these conditions, side effects of ASA, mainly gastrointestinal (e.g., nausea, epigastric pain or discomfort, and bleeding), were rare and generally related to the long-term use of high ASA doses [129, 130].

Long-term use of low doses of ASA are currently the mainstay of secondary prevention of ischemic cardiovascular diseases [131]. The benefit-to-risk ratio of using low-dose ASA in this specific population is highly favorable when considering the number of ischemic events prevented [130] and the potential risk of significant adverse events (i.e., gastrointestinal bleeding) [132]. The relatively low risk of serious bleeding in younger individuals becomes significantly higher in older individuals (aged $\geq 75$ years) [133] and it has been shown to be greatly reduced by the concomitant use of proton-pump inhibitors or $\mathrm{H}_{2}$-receptor antagonists [134].

The main safety concern related to the prophylactic use of low doses of ASA for the prevention of thrombotic complications during pregnancy is the potential bleeding risk.
According to available evidence, the benefit-to-risk ratio of ASA use for this indication is unfavorable only in thrombocytopenic women and in the third trimester of pregnancy, when ASA could contribute to severe bleeding in women, and cesarean delivery may be urgently indicated in different maternal conditions [86, 87]. Therefore, a careful evaluation of gestational age and platelet count should be taken into account when starting ASA in pregnancy.

Short-term use of high doses of ASA in children with infections (e.g., mostly influenza A and B, varicella, but also other viral and bacterial infections) has been associated with the occurrence of a rare but life-threatening complication called Reye's syndrome [135, 136]. This is characterized by the concomitant onset of an acute non-inflammatory encephalopathy and fatty liver failure $[135,136]$. The incidence of Reye's syndrome fell from 0.6 to 0.1 cases per 100,000 in the UK following the warning against the use of ASA in children [136]. Although it is typically observed in children, very rare cases of Reye's syndrome have been reported among adults [137]. Rare cases of children with Reye's syndrome who did not have side effects when ASA rechallenge was attempted in adulthood have been described [138].

Finally, the use of ASA for the treatment of either the common cold or flu symptoms in adults is generally safe and with side effects that are numerically comparable to those from other non-steroidal anti-inflammatory drugs (e.g., ibuprofen) or paracetamol [139]. However, attention should be paid when considering the use of ASA in specific populations [16].

\section{Potential Role of Acetylsalicylic Acid in COVID-19}

The use of non-steroidal anti-inflammatory drugs (NSAIDs), including ASA, in COVID-19 patients has been a matter of intense debate. Indeed, based on some previous reports on acute respiratory infections, concerns have been raised regarding a possible increased risk of adverse events (e.g., multi-organ failure, ARDS, and death) with the use of NSAIDs in COVID-19 [87, 140]. Supporting this notion, experimental evidence suggests that these drugs may alter neutrophil function, thereby negatively influencing resolution of inflammation in acute respiratory infections [141]. Nonetheless, major scientific societies and regulatory authorities worldwide have produced advisory documents to discourage either avoidance or discontinuation of NSAIDs in COVID-19, given the absence of a high level of evidence on their possible association with severe adverse outcomes in this specific setting [142-144].

Conversely, It should be considered that among NSAIDs, ASA has multifaceted pharmacological properties, which could exert potential benefits and provide a 
rationale for its use as supportive therapy in COVID-19 patients. First, it may be useful for the relief of aspecific symptoms of COVID-19, due to its analgesic and antipyretic effects [16]. Second, it may exert anti-inflammatory, antithrombotic, and antiviral effects $[16,18,20,81,85$, 131], which altogether may be useful to inhibit the pathophysiological processes leading to the most severe clinical manifestations of COVID-19. Hence, ASA might reasonably be a therapeutic candidate to be tested in COVID-19. Timing of ASA initiation, dosing, duration of treatment, and subgroups of COVID-19 patients that can benefit most from the antiviral, anti-inflammatory, and antithrombotic actions of ASA need to be established (Table 1). The clinical context of possible use of ASA should also be evaluated with caution in the light of the benefit-to-risk ratio. In this regard, side effects of and contraindications to ASA must always be kept in mind, with particular reference to bleeding risk (either in patients taking ASA for the prevention of cardiovascular events or in women taking ASA for the prevention of thrombotic complications in pregnancy) and Reye's syndrome onset in children. Hence, patients at increased risk of bleeding and children should be excluded from ASA treatment. However, the epidemiological observation that children are markedly less likely to develop COVID-19 and its outcomes deserves attention [145]. Also, it should be considered that there is no current evidence suggesting that low doses of ASA in COVID-19 pregnant women or in COVID-19 patients at high/very high cardiovascular risk are associated with an increased risk of bleeding.

To our knowledge a number of observational and interventional studies are currently investigating the efficacy and safety of this drug at different doses in COVID-19 (Table 1). Results from these studies will be crucial to either validate or refute the hypothesis that ASA could be a safe and potentially useful choice for adult patients with COVID-19.

\section{Conclusions}

COVID-19 has presented a serious challenge for the entire world, causing tremendous health, social, and economic consequences. From a pathophysiological perspective, much of the clinical consequences of SARS-CoV-2 infection are due to the elevated viral infectiveness and the ability of the virus to produce significant injury in the respiratory tract [2-6]. SARS-CoV-2 is also able to overactivate local and systemic inflammation cascades, and to promote a detrimental and progressive state of hyper-coagulability and platelet aggregability leading to micro- and macro-vascular thrombotic events [7-9]. This latter binomium of pathological events evoked by the viral infection configures the so-called state of thrombo-inflammation, an event that has been observed in other viral and non-viral infections [58].

Currently, there is no specific pharmacological recommendation for the treatment of COVID-19, though antiviral, immune-modulatory, anti-inflammatory, and antithrombotic agents are currently used and other drugs are being tested in clinical trials [39-42]. Also, a vaccine against SARS-CoV-2 is not yet available. Hence, current treatment strategies need to be repurposed and targeted against the thrombo-inflammation cascade. In this regard, the long-lasting use of ASA as an anti-inflammatory and antithrombotic agent has been documented over decades [16, 18]. In addition to the antiinflammatory and antiplatelet effects of ASA, much solid evidence from in vitro and experimental models supports the capacity of ASA to reduce replication, propagation, and infectivity of several RNA-enveloped viruses, including human CoV-229E and MERS-CoV [20]. Also, ASA improved survival among patients with different types of infections, the latter conditions being characterized by overactivation of the inflammation cascade and enhanced platelet reactivity [96-101]. Altogether, these data, along with the recognized ability of ASA to mitigate several symptoms related to common viral infections, might support the notion to include ASA among the drugs deserving to be tested in patients with COVID-19. Overall, a critical appraisal of the clinical effects derived from testing ASA in adults with COVID-19 would add much to a still incomplete knowledge base and, hopefully, improve our ability to mitigate the disastrous clinical consequences of SARS-CoV-2 infection.

Acknowledgement Open access funding provided by Universitá degli Studi di Perugia within the CRUI-CARE Agreement.

Author Contributions MP and VB produced the idea for the article; all the authors performed the literature search and data analysis, and drafted and critically revised the manuscript.

\section{Declarations}

Funding No external funding was used in the preparation of this manuscript.

Conflict of interest Vanessa Bianconi, Francesco Violi, Francesca Fallarino, Pasquale Pignatelli, Amirhossein Sahebkar, and Matteo Pirro declare that they have no potential conflicts of interest that might be relevant to the contents of this article.

Open Access This article is licensed under a Creative Commons Attribution-NonCommercial 4.0 International License, which permits any non-commercial use, sharing, adaptation, distribution and reproduction in any medium or format, as long as you give appropriate credit to the original author(s) and the source, provide a link to the Creative Commons licence, and indicate if changes were made. The images or other third party material in this article are included in the article's Creative Commons licence, unless indicated otherwise in a credit line to the material. If material is not included in the article's Creative Commons licence and your intended use is not permitted by statutory 
regulation or exceeds the permitted use, you will need to obtain permission directly from the copyright holder. To view a copy of this licence, visit http://creativecommons.org/licenses/by-nc/4.0/.

\section{References}

1. Coronavirus disease 2019 (COVID-19) Situation Report-166. Data as received by WHO from national authorities by 10:00 CET. 2020. https://www.who.int/docs/default-source/coronaviru se/situation-reports/20200704-covid-19-sitrep-166.pdf?sfvrs $\mathrm{n}=6247972$. 6 .

2. Wölfel R, Corman VM, Guggemos W, Seilmaier M, Zange S, Müller MA, Niemeyer D, Jones TC, Vollmar P, Rothe C, Hoelscher M, Bleicker T, Brünink S, Schneider J, Ehmann R, Zwirglmaier K, Drosten C, Wendtner C. Virological assessment of hospitalized patients with COVID-2019. Nature. 2020;581:465-9.

3. Zhang H, Zhou P, Wei Y, Yue H, Wang Y, Hu M, Zhang S, Cao T, Yang C, Li M, Guo G, Chen X, Chen Y, Lei M, Liu H, Zhao J, Peng P, Wang CY, Du R. Histopathologic CHANGES and SARS-CoV-2 immunostaining in the lung of a patient with COVID-19. Ann Intern Med. 2020;172:629-32.

4. Guan WJ, Ni ZY, Hu Y, Liang WH, Ou CQ, He JX, Liu L, Shan H, Lei CL, Hui DSC, Du B, Li LJ, Zeng G, Yuen KY, Chen RC, Tang CL, Wang T, Chen PY, Xiang J, Li SY, Wang JL, Liang ZJ, Peng YX, Wei L, Liu Y, Hu YH, Peng P, Wang JM, Liu JY, Chen Z, Li G, Zheng ZJ, Qiu SQ, Luo J, Ye CJ, Zhu SY, Zhong NS, China Medical Treatment Expert Group for Covid-19. Clinical characteristics of coronavirus disease 2019 in China. N Engl J Med. 2020;382:1708-20.

5. Mehta P, McAuley DF, Brown M, Sanchez E, Tattersall RS, Manson JJ, HLH Across Speciality Collaboration, UK. COVID19: consider cytokine storm syndromes and immunosuppression. Lancet. 2020;395:1033-4.

6. Chen T, Wu D, Chen H, Yan W, Yang D, Chen G, Ma K, Xu D, Yu H, Wang H, Wang T, Guo W, Chen J, Ding C, Zhang X, Huang J, Han M, Li S, Luo X, Zhao J, Ning Q. Clinical characteristics of 113 deceased patients with coronavirus disease 2019: retrospective study. BMJ. 2020;368:m1091.

7. Cui S, Chen S, Li X, Liu S, Wang F. Prevalence of venous thromboembolism in patients with severe novel coronavirus pneumonia. J Thromb Haemost. 2020;18:1421-4.

8. Giannis D, Ziogas IA, Gianni P. Coagulation disorders in coronavirus infected patients: COVID-19, SARSCoV-1, MERS-CoV and lessons from the past. J Clin Virol. 2020;127:104362.

9. Terpos E, Ntanasis-Stathopoulos I, Elalamy I, Kastritis E, Sergentanis TN, Politou M, Psaltopoulou T, Gerotziafas G, Dimopoulos MA. Hematological findings and complications of COVID-19. Am J Hematol. 2020;95:834-47.

10. Subramaniam S, Scharrer I. Procoagulant activity during viral infections. Front Biosci (Landmark Ed). 2018;23:1060-81.

11. Assinger A. Platelets and infection-an emerging role of platelets in viral infection. Front Immunol. 2014;5:649.

12. Chen CY, Poole EM, Ulrich CM, Kulmacz RJ, Wang LH. Functional analysis of human thromboxane synthase polymorphic variants. Pharmacogenet Genomics. 2012;22:653-8.

13. Panigrahi S, Ma Y, Hong L, Gao D, West XZ, Salomon RG, Byzova TV, Podrez EA. Engagement of platelet toll-like receptor 9 by novel endogenous ligands promotes platelet hyperreactivity and thrombosis. Circ Res. 2013;112:103-12.

14. Ng LF, Hibberd ML, Ooi EE, Tang KF, Neo SY, Tan J, Murthy KR, Vega VB, Chia JM, Liu ET, Ren EC. A human in vitro model system for investigating genome-wide host responses to SARS coronavirus infection. BMC Infect Dis. 2004;4:34.
15. Cangemi R, Casciaro M, Rossi E, Calvieri C, Bucci T, Calabrese CM, Taliani G, Falcone M, Palange P, Bertazzoni G, Farcomeni A, Grieco S, Pignatelli P, Violi F. Platelet activation is associated with myocardial infarction in patients with pneumonia. J Am Coll Cardiol. 2014;64:1917-25.

16. Arif H, Aggarwal S. Salicylic Acid (Aspirin). In: StatPearls. Treasure Island (FL): StatPearls Publishing; 2020.

17. Amin AR, Attur MG, Pillinger M, Abramson SB. The pleiotropic functions of aspirin: mechanisms of action. Cell Mol Life Sci. 1999;56:305-12.

18. Crescente M, Menke L, Chan MV, Armstrong PC, Warner TD. Eicosanoids in platelets and the effect of their modulation by aspirin in the cardiovascular system (and beyond). Br J Pharmacol. 2019;176:988-99.

19. Glatthaar-Saalmüller B, Mair KH, Saalmüller A. Antiviral activity of aspirin against RNA viruses of the respiratory tract-an in vitro study. Influenza Other Respir Viruses. 2017;11:85-92.

20. Müller C, Karl N, Ziebuhr J, Pleschka S. D,L-Lysine acetylsalicylate + glycine impairs coronavirus replication. J Antivir Antiretrovir. 2016;8(4):142-50.

21. Huang C, Wang Y, Li X, Ren L, Zhao J, Hu Y, Zhang L, Fan G, Xu J, Gu X, Cheng Z, Yu T, Xia J, Wei Y, Wu W, Xie X, Yin W, Li H, Liu M, Xiao Y, Gao H, Guo L, Xie J, Wang G, Jiang R, Gao Z, Jin Q, Wang J, Cao B. Clinical features of patients infected with 2019 novel coronavirus in Wuhan, China. Lancet. 2020;395:497-506.

22. Feldstein LR, Rose EB, Horwitz SM, Collins JP, Newhams MM, Son MBF, Newburger JW, Kleinman LC, Heidemann SM, Martin AA, Singh AR, Li S, Tarquinio KM, Jaggi P, Oster ME, Zackai SP, Gillen J, Ratner AJ, Walsh RF, Fitzgerald JC, Keenaghan MA, Alharash H, Doymaz S, Clouser KN, Giuliano JS Jr, Gupta A, Parker RM, Maddux AB, Havalad V, Ramsingh S, Bukulmez H, Bradford TT, Smith LS, Tenforde MW, Carroll CL, Riggs BJ, Gertz SJ, Daube A, Lansell A, Munoz AC, Hobbs CV, Marohn KL, Halasa NB, Patel MM, Randolph AG. Multisystem inflammatory syndrome in US children and adolescents. N Engl J Med. 2020. https://doi.org/10.1056/NEJMo a2021680.

23. Rodriguez-Morales AJ, Cardona-Ospina JA, Gutiérrez-Ocampo E, Villamizar-Peña R, Holguin-Rivera Y, Escalera-Antezana JP, Alvarado-Arnez LE, Bonilla-Aldana DK, Franco-Paredes C, Henao-Martinez AF, Paniz-Mondolfi A, Lagos-Grisales GJ, Ramírez-Vallejo E, Suárez JA, Zambrano LI, Villamil-Gómez WE, Balbin-Ramon GJ, Rabaan AA, Harapan H, Dhama K, Nishiura H, Kataoka H, Ahmad T, Sah R. Latin American Network of Coronavirus Disease 2019-COVID-19 Research (LANCOVID-19) Clinical, laboratory and imaging features of COVID19: a systematic review and meta-analysis. Travel Med Infect Dis. 2020;34:101623.

24. Lechien JR, Chiesa-Estomba CM, De Siati DR, Horoi M, Le Bon SD, Rodriguez A, Dequanter D, Blecic S, El Afia F, Distinguin L, Chekkoury-Idrissi Y, Hans S, Delgado IL, Calvo-Henriquez C, Lavigne P, Falanga C, Barillari MR, Cammaroto G, Khalife M, Leich P, Souchay C, Rossi C, Journe F, Hsieh J, Edjlali M, Carlier R, Ris L, Lovato A, De Filippis C, Coppee F, Fakhry N, Ayad T, Saussez S. Olfactory and gustatory dysfunctions as a clinical presentation of mild-to-moderate forms of the coronavirus disease (COVID-19): a multicenter European study. Eur Arch Otorhinolaryngol. 2020;6:1-11.

25. Zhu J, Ji P, Pang J, Zhong Z, Li H, He C, Zhang J, Zhao C. Clinical characteristics of 3062 COVID-19 patients: a meta-analysis. J Med Virol. 2020. https://doi.org/10.1002/jmv.25884.

26. Li Q, Guan X, Wu P, Wang X, Zhou L, Tong Y, Ren R, Leung KSM, Lau EHY, Wong JY, Xing X, Xiang N, Wu Y, Li C, Chen Q, Li D, Liu T, Zhao J, Liu M, Tu W, Chen C, Jin L, Yang R, Wang Q, Zhou S, Wang R, Liu H, Luo Y, Liu Y, Shao G, Li H, 
Tao Z, Yang Y, Deng Z, Liu B, Ma Z, Zhang Y, Shi G, Lam TTY, Wu JT, Gao GF, Cowling BJ, Yang B, Leung GM, Feng Z. Early transmission dynamics in Wuhan, China, of novel coronavirusinfected pneumonia. N Engl J Med. 2020;382:1199-207.

27. Emami A, Javanmardi F, Pirbonyeh N, Akbari A. Prevalence of underlying diseases in hospitalized patients with COVID-19: a systematic review and meta-analysis. Arch Acad Emerg Med. 2020;8:e35.

28. Clerkin KJ, Fried JA, Raikhelkar J, Sayer G, Griffin JM, Masoumi A, Jain SS, Burkhoff D, Kumaraiah D, Rabbani L, Schwartz A, Uriel N. Coronavirus Disease 2019 (COVID-19) and cardiovascular disease. Circulation. 2020;141:1648-55.

29. Yang X, Yu Y, Xu J, Shu H, Xia J, Liu H, Wu Y, Zhang L, Yu Z, Fang M, Yu T, Wang Y, Pan S, Zou X, Yuan S, Shang Y. Clinical course and outcomes of critically ill patients with SARS-CoV-2 pneumonia in Wuhan, China: a single-centered, retrospective, observational study. Lancet Respir Med. 2020;8(5):475-81.

30. Siripanthong B, Nazarian S, Muser D, Deo R, Santangeli P, Khanji MY, Cooper LT Jr, Chahal CAA. Recognizing COVID19-related myocarditis: the possible pathophysiology and proposed guideline for diagnosis and management. Heart Rhythm. 2020;S1547-5271(20):30422-7.

31. Shi S, Qin M, Shen B, Cai Y, Liu T, Yang F, Gong W, Liu X, Liang J, Zhao Q, Huang H, Yang B, Huang C. Association of Cardiac Injury With Mortality in Hospitalized Patients With COVID-19 in Wuhan. China. JAMA Cardiol. 2020;5:802-10.

32. Wu Z, McGoogan JM. Characteristics of and important lessons from the Coronavirus Disease 2019 (COVID-19) Outbreak in China: summary of a report of 72,314 cases from the Chinese Center for Disease Control and Prevention. JAMA. 2020. https ://doi.org/10.1001/jama.2020.2648.

33. Guo T, Fan Y, Chen M, Wu X, Zhang L, He T, Wang H, Wan J, Wang X, Lu Z. Cardiovascular Implications of Fatal Outcomes of Patients With Coronavirus Disease 2019 (COVID-19). JAMA Cardiol. 2020;27(5):1-8.

34. Zhou F, Yu T, Du R, Fan G, Liu Y, Liu Z, Xiang J, Wang Y, Song B, Gu X, Guan L, Wei Y, Li H, Wu X, Xu J, Tu S, Zhang Y, Chen $\mathrm{H}$, Cao B. Clinical course and risk factors for mortality of adult in patients with COVID-19 in Wuhan, China: a retrospective cohort study. Lancet. 2020;395:1054-62.

35. Arachchillage DR, Laffan M. Abnormal coagulation parameters are associated with poor prognosis in patients with novel coronavirus pneumonia. J Thromb Haemost. 2020;18:1233-4.

36. Liu Y, Sun W, Guo Y, Chen L, Zhang L, Zhao S, Long D, Yu L. Association between platelet parameters and mortality in coronavirus disease 2019: retrospective cohort study. Platelets. 2020:31:490-6.

37. Gao L, Jiang D, Wen XS, Cheng XC, Sun M, He B, You LN, Lei P, Tan XW, Qin S, Cai GQ, Zhang DY. Prognostic value of NT-proBNP in patients with severe COVID-19. Respir Res. 2020;21:83.

38. Du RH, Liang LR, Yang CQ, Wang W, Cao TZ, Li M, Guo GY, Du J, Zheng CL, Zhu Q, Hu M, Li XY, Peng P, Shi HZ. Predictors of mortality for patients with COVID-19 pneumonia caused by SARS-CoV-2: a prospective cohort study. Eur Respir J. 2020;55:2000524.

39. Li SR, Tang ZJ, Li ZH, Liu X. Searching therapeutic strategy of new coronavirus pneumonia from angiotensin-converting enzyme 2: the target of COVID-19 and SARS-CoV. Eur J Clin Microbiol Infect Dis. 2020;39:1021-6.

40. Sanders JM, Monogue ML, Jodlowski TZ, Cutrell JB. Pharmacologic treatments for Coronavirus Disease 2019 (COVID-19): a review. JAMA. 2020. https://doi.org/10.1001/jama.2020.6019.

41. Martinez MA. Compounds with therapeutic potential against Novel Respiratory 2019 Coronavirus. Antimicrob Agents Chemother. 2020;64:e00399-e420.
42. Saber-Ayad M, Saleh MA, Abu-Gharbieh E. The rationale for potential pharmacotherapy of COVID-19. Pharmaceuticals (Basel). 2020;13:96.

43. Di Lorenzo G, Di Trolio R, Kozlakidis Z, Busto G, Ingenito C, Buonerba L, Ferrara C, Libroia A, Ragone G, Ioio CD, Savastano B, Polverino M, De Falco F, Iaccarino S, Leo E. COVID 19 therapies and anti-cancer drugs: a systematic review of recent literature. Crit Rev Oncol Hematol. 2020;152:102991.

44. Tang BS, Chan KH, Cheng VC, Woo PC, Lau SK, Lam CC, Chan TL, Wu AK, Hung IF, Leung SY, Yuen KY. Comparative host gene transcription by microarray analysis early after infection of the Huh7 cell line by severe acute respiratory syndrome coronavirus and human coronavirus 229E. J Virol. 2005;79:6180-93.

45. Li K, Wohlford-Lenane C, Perlman S, Zhao J, Jewell AK, Reznikov LR, Gibson-Corley KN, Meyerholz DK, McCray PB Jr. Middle east respiratory syndrome coronavirus causes multiple organ damage and lethal disease in mice transgenic for human dipeptidyl peptidase 4. J Infect Dis. 2016;213:712-22.

46. Ng KH, Wu AK, Cheng VC, Tang BS, Chan CY, Yung CY, Luk SH, Lee TW, Chow L, Yuen KY. Pulmonary artery thrombosis in a patient with severe acute respiratory syndrome. Postgrad Med J. 2005;81:e3.

47. Singh SK. Middle east respiratory syndrome virus pathogenesis. Semin Respir Crit Care Med. 2016;37:572-7.

48. Lippi G, Plebani M, Henry BM. Thrombocytopenia is associated with severe coronavirus disease 2019 (COVID-19) infections: a meta-analysis. Clin Chim Acta. 2020;506:145-8.

49. Han H, Yang L, Liu R, Liu F, Wu KL, Li J, Liu XH, Zhu CL. Prominent changes in blood coagulation of patients with SARS-CoV-2 infection. Clin Chem Lab Med. 2020;58:1116-20.

50. Tang N, Li D, Wang X, Sun Z. Abnormal coagulation parameters are associated with poor prognosis in patients with novel coronavirus pneumonia. J Thromb Haemost. 2020;18:844-7.

51. Lillicrap D. Disseminated intravascular coagulation in patients with 2019-nCoV pneumonia. J Thromb Haemost. 2020;18:786-7.

52. Dolhnikoff M, Duarte-Neto AN, de Almeida Monteiro RA, da Silva LFF, de Oliveira EP, Saldiva PHN, Mauad T, Negri EM. Pathological evidence of pulmonary thrombotic phenomena in severe COVID-19. J Thromb Haemost. 2020;18:1517-9.

53. Klok FA, Kruip MJHA, van der Meer NJM, Arbous MS, Gommers DAMPJ, Kant KM, Kaptein FHJ, van Paassen J, Stals MAM, Huisman MV, Endeman H. Incidence of thrombotic complications in critically ill ICU patients with COVID-19. Thromb Res. 2020;191:145-7.

54. Zhang Y, Xiao M, Zhang S, Xia P, Cao W, Jiang W, Chen H, Ding X, Zhao H, Zhang H, Wang C, Zhao J, Sun X, Tian R, Wu W, Wu D, Ma J, Chen Y, Zhang D, Xie J, Yan X, Zhou X, Liu Z, Wang J, Du B, Qin Y, Gao P, Qin X, Xu Y, Zhang W, Li T, Zhang F, Zhao Y, Li Y, Zhang S. Coagulopathy and antiphospholipid antibodies in patients with Covid-19. N Engl J Med. 2020;382:e38.

55. Mendoza-Pinto C, García-Carrasco M, Cervera R. Role of infectious diseases in the antiphospholipid syndrome (including its catastrophic variant). Curr Rheumatol Rep. 2018;20:62.

56. Abdel-Wahab N, Talathi S, Lopez-Olivo MA, Suarez-Almazor ME. Risk of developing antiphospholipid antibodies following viral infection: a systematic review and meta-analysis. Lupus. 2018;27:572-83.

57. Atri D, Siddiqi HK, Lang J, Nauffal V, Morrow DA, Bohula EA. COVID-19 for the cardiologist: a current review of the virology, clinical epidemiology, cardiac and other clinical manifestations and potential therapeutic strategies. JACC Basic Transl Sci. 2020;5:518-36. 
58. Beristain-Covarrubias N, Perez-Toledo M, Thomas MR, Henderson IR, Watson SP, Cunningham AF. Understanding infectioninduced thrombosis: lessons learned from animal models. Front Immunol. 2019;10:2569.

59. Poterucha TJ, Libby P, Goldhaber SZ. More than an anticoagulant: do heparins have direct anti-inflammatory effects? Thromb Haemost. 2017;117:437-44.

60. Tang N, Bai H, Chen X, Gong J, Li D, Sun Z. Anticoagulant treatment is associated with decreased mortality in severe coronavirus disease 2019 patients with coagulopathy. J Thromb Haemost. 2020;18:1094-9.

61. Bikdeli B, Madhavan MV, Jimenez D, Chuich T, Dreyfus I, Driggin E, Nigoghossian CD, Ageno W, Madjid M, Guo Y, Tang LV, Hu Y, Giri J, Cushman M, Quéré I, Dimakakos EP, Gibson CM, Lippi G, Favaloro EJ, Fareed J, Caprini JA, Tafur AJ, Burton JR, Francese DP, Wang EY, Falanga A, McLintock C, Hunt BJ, Spyropoulos AC, Barnes GD, Eikelboom JW, Weinberg I, Schulman S, Carrier M, Piazza G, Beckman JA, Steg PG, Stone GW, Rosenkranz S, Goldhaber SZ, Parikh SA, Monreal M, Krumholz HM, Konstantinides SV, Weitz JI, Lip GYH. COVID-19 and thrombotic or thromboembolic disease: implications for prevention, antithrombotic therapy, and follow-up: JACC State-of-theArt Review. JACC. 2020;75:2950-73.

62. Zidar N, Odar K, Glavac D, Jerse M, Zupanc T, Stajer D. Cyclooxygenase in normal human tissues - is COX-1 really a constitutive isoform, and COX-2 an inducible isoform? J Cell Mol Med. 2009;13:3753-63.

63. Paseban M, Marjaneh RM, Banach M, Riahi MM, Bo S, Sahebkar A. Modulation of microRNAs by aspirin in cardiovascular disease. Trends Cardiovasc Med. 2020;30:249-54.

64. Nathan C. Points of control in inflammation. Nature. 2002;420:846-52.

65. Sabari BR, Zhang D, Allis CD, Zhao Y. Metabolic regulation of gene expression through histone acylations. Nat Rev Mol Cell Biol. 2017;18:90-101

66. Yin MJ, Yamamoto Y, Gaynor RB. The anti-inflammatory agents aspirin and salicylate inhibit the activity of I(kappa)B kinasebeta. Nature. 1998;396:77-80.

67. Grosser N, Abate A, Oberle S, Vreman HJ, Dennery PA, Becker JC, Pohle T, Seidman DS, Schröder H. Heme oxygenase-1 induction may explain the antioxidant profile of aspirin. Biochem Biophys Res Commun. 2003;308:956-60.

68. Taubert D, Berkels R, Grosser N, Schröder H, Gründemann D, Schömig E. Aspirin induces nitric oxide release from vascular endothelium: a novel mechanism of action. Br J Pharmacol. 2004;143:159-65.

69. Cilliers A, Adler AJ, Saloojee H. Anti-inflammatory treatment for carditis in acute rheumatic fever. Cochrane Database Syst Rev. 2015;5:CD003176.

70. Wang J, Chen H, Shi H, Zhang X, Shao Y, Hang B, Xu Z, Rong X, Chu M, Qiu H. Effect of different doses of aspirin on the prognosis of Kawasaki disease. Pediatr Rheumatol Online J. 2020;18:48.

71. Riera E, Olivé A, Narváez J, Holgado S, Santo P, Mateo L, Bianchi MM, Nolla JM. Adult onset Still's disease: review of 41 cases. Clin Exp Rheumatol. 2011;29:331-6.

72. Cacoub P, Marques C. Acute recurrent pericarditis: from pathophysiology towards new treatment strategy. Heart. 2020;106:1046-51.

73. Sakulchit T, Benseler SM, Goldman RD. Acetylsalicylic acid for children with Kawasaki disease. Can Fam Phys. 2017;63:607-9.

74. Ralph AP, Noonan S, Boardman C, Halkon C, Currie BJ. Prescribing for people with acute rheumatic fever. Aust Prescr. 2017;40:70-5.

75. Bachert C, Chuchalin AG, Eisebitt R, Netayzhenko VZ, Voelker M. Aspirin compared with acetaminophen in the treatment of fever and other symptoms of upper respiratory tract infection in adults: a multicenter, randomized, double-blind, double-dummy, placebo-controlled, parallel-group, single-dose, 6-hour doseranging study. Clin Ther. 2005;27:993-1003.

76. Eccles R, Loose I, Jawad M, Nyman L. Effects of acetylsalicylic acid on sore throat pain and other pain symptoms associated with acute upper respiratory tract infection. Pain Med. 2003;4:118-24.

77. Steer SA, Corbett JA. The role and regulation of COX-2 during viral infection. Viral Immunol. 2003;16:447-60.

78. Rucker D, Dhamoon AS. Physiology, Thromboxane A2. In: StatPearls. Treasure Island (FL): StatPearls Publishing; 2020.

79. Warner TD, Nylander S, Whatling C. Antiplatelet therapy: cyclo-oxygenase inhibition and the use of aspirin with particular regard to dual antiplatelet therapy. Br J Clin Pharmacol. 2011;72:619-33.

80. Patrono C, Rocca B. Measurement of thromboxane biosynthesis in health and disease. Front Pharmacol. 2019;10:1244.

81. Amsterdam EA, Wenger NK, Brindis RG, Casey DE Jr, Ganiats TG, Holmes DR Jr, Jaffe AS, Jneid H, Kelly RF, Kontos MC, Levine GN, Liebson PR, Mukherjee D, Peterson ED, Sabatine MS, Smalling RW, Zieman SJ. 2014 AHA/ACC guideline for the management of patients with non-st-elevation acute coronary syndromes: a report of the American College of Cardiology/American Heart Association Task Force on Practice Guidelines [published correction appears in J Am Coll Cardiol. 2014;64:2713-4. Dosage error in article text]. J Am Coll Cardiol. 2014;64:e139-e228.

82. Patrono C, García Rodríguez LA, Landolfi R, Baigent C. Lowdose aspirin for the prevention of atherothrombosis. N Engl J Med. 2005;353:2373-83.

83. Antithrombotic Trialists' (ATT) Collaboration, Baigent C, Blackwell L, Collins R, Emberson J, Godwin J, Peto R, Buring J, Hennekens C, Kearney P, Meade T, Patrono C, Roncaglioni MC, Zanchetti A. Aspirin in the primary and secondary prevention of vascular disease: collaborative meta-analysis of individual participant data from randomised trials. Lancet. 2009;373:1849-60.

84. Patrono C, Baigent C, Hirsh J, Roth G. Antiplatelet drugs: American College of Chest Physicians Evidence-Based Clinical Practice Guidelines (8th Edition). Chest. 2008;133:199S-233S.

85. Knuuti J, Wijns W, Saraste A, Capodanno D, Barbato E, FunckBrentano C, Prescott E, Storey RF, Deaton C, Cuisset T, Agewall S, Dickstein K, Edvardsen T, Escaned J, Gersh BJ, Svitil P, Gilard M, Hasdai D, Hatala R, Mahfoud F, Masip J, Muneretto C, Valgimigli M, Achenbach S, Bax JJ, ESC Scientific Document Group. 2019 ESC Guidelines for the diagnosis and management of chronic coronary syndromes. Eur Heart J. 2020;41:407-77.

86. Gavillet M, Rolnik DL, Hoffman MK, Panchaud A, Baud D. Should we stop aspirin prophylaxis in pregnant women diagnosed with COVID-19? Ultrasound Obstet Gynecol. 2020;55:843-4.

87. Kwiatkowski S, Borowski D, Kajdi A, Poon LC, Rokita W, Wielgos M. Why we should not stop giving aspirin to pregnant women during the COVID-19 pandemic. Ultrasound Obstet Gynecol. 2020;55:841-3.

88. Simes J, Becattini C, Agnelli G, Eikelboom JW, Kirby AC, Mister R, Prandoni P, Brighton TA, INSPIRE Study Investigators (International Collaboration of Aspirin Trials for Recurrent Venous Thromboembolism). Aspirin for the prevention of recurrent venous thromboembolism: the INSPIRE collaboration. Circulation. 2014;130:1062-71.

89. Undas A, Brummel-Ziedins KE, Mann KG. Antithrombotic properties of aspirin and resistance to aspirin: beyond strictly antiplatelet actions. Blood. 2007;109:2285-92.

90. Matharu GS, Kunutsor SK, Judge A, Blom AW, Whitehouse MR. Clinical effectiveness and safety of aspirin for venous thromboembolism prophylaxis after total hip and knee replacement: 
a systematic review and meta-analysis of randomized clinical trials. JAMA Intern Med. 2020;180:376-84.

91. Weitz JI, Chan NC. Long-term management of venous thromboembolism: lessons from EINSTEIN CHOICE and other extension trials. Thromb Haemost. 2019;119:689-94.

92. Weitz JI, Lensing AWA, Prins MH, Bauersachs R, Beyer-Westendorf J, Bounameaux H, Brighton TA, Cohen AT, Davidson BL, Decousus H, Freitas MCS, Holberg G, Kakkar AK, Haskell L, van Bellen B, Pap AF, Berkowitz SD, Verhamme P, Wells PS, Prandoni P, EINSTEIN CHOICE Investigators. Rivaroxaban or aspirin for extended treatment of venous thromboembolism. N Engl J Med. 2017;376:1211-22.

93. Carestia A, Davis RP, Grosjean H, Lau MW, Jenne CN. Acetylsalicylic acid inhibits intravascular coagulation during Staphylococcus aureus-induced sepsis in mice. Blood. 2020;135:1281-6.

94. Kelm DJ, Valerio-Rojas JC, Cabello-Garza J, Gajic O, CartinCeba R. Predictors of disseminated intravascular coagulation in patients with septic shock. ISRN Crit Care. 2013;219048:1-6.

95. Koo YM, Heo AY, Choi HW. Salicylic acid as a safe plant protector and growth regulator. Plant Pathol J. 2020;36:1-10.

96. Speir E, Yu ZX, Ferrans VJ, Huang ES, Epstein SE. Aspirin attenuates cytomegalovirus infectivity and gene expression mediated by cyclooxygenase- 2 in coronary artery smooth muscle cells. Circ Res. 1998;83:210-6.

97. Primache V, Binda S, De Benedittis G, Barbi M. In vitro activity of acetylsalicylic acid on replication of varicella-zoster virus. New Microbiol. 1998;21:397-401.

98. Walz-Cicconi MA, Weller TH. Dose-related effect of acetylsalicylic acid on replication of varicella zoster virus in vitro. Proc Natl Acad Sci USA. 1984;81:5223-6.

99. Sánchez-García A, Ríos-Ibarra CP, Rincón-Sánchez AR, OrtizLópez R, Garza-Juárez A, Morlett-Chávez J, Martínez-Rodríguez $\mathrm{H}$, Rivas-Estilla AM. Use of proteomic analysis tools to identify HCV-proteins down-regulated by acetylsalicylic acid. Ann Hepatol. 2013;12:725-32.

100. Trujillo-Murillo K, Rincón-Sánchez AR, Martínez-Rodríguez H, Bosques-Padilla F, Ramos-Jiménez J, Barrera-Saldaña HA, Rojkind M, Rivas-Estilla AM. Acetylsalicylic acid inhibits hepatitis $\mathrm{C}$ virus RNA and protein expression through cyclooxygenase 2 signaling pathways. Hepatology. 2008;47:1462-72.

101. Yin $P$, Zhang L. Aspirin inhibits hepatitis $C$ virus entry by downregulating claudin-1. J Viral Hepat. 2016;23:62-4.

102. Ríos-Ibarra CP, Lozano-Sepulveda S, Muñoz-Espinosa L, Rincón-Sánchez AR, Cordova-Fletes C, Rivas-Estilla AM. Downregulation of inducible nitric oxide synthase (iNOS) expression is implicated in the antiviral activity of acetylsalicylic acid in HCV-expressing cells. Arch Virol. 2014;159:3321-8.

103. Rivas-Estilla AM, Bryan-Marrugo OL, Trujillo-Murillo K, Pérez-Ibave D, Charles-Niño C, Pedroza-Roldan C, Ríos-Ibarra C, Ramírez-Valles E, Ortiz-López R, Islas-Carbajal MC, Nieto N, Rincón-Sánchez AR. Cu/Zn superoxide dismutase (SOD1) induction is implicated in the antioxidative and antiviral activity of acetylsalicylic acid in HCV-expressing cells. Am J Physiol Gastrointest Liver Physiol. 2012;302:G1264-G12731273.

104. Coulombe F, Jaworska J, Verway M, Tzelepis F, Massoud A, Gillard J, Wong G, Kobinger G, Xing Z, Couture C, Joubert P, Fritz JH, Powell WS, Divangahi M. Targeted prostaglandin E2 inhibition enhances antiviral immunity through induction of type I interferon and apoptosis in macrophages. Immunity. 2014;40:554-68.

105. Wu B, Wu Y, Tang W. Heme catabolic pathway in inflammation and immune disorders. Front Pharmacol. 2019;10:825.

106. Hashiba T, Suzuki M, Nagashima Y, Suzuki S, Inoue S, Tsuburai $\mathrm{T}$, Matsuse T, Ishigatubo Y. Adenovirus-mediated transfer of heme oxygenase- 1 cDNA attenuates severe lung injury induced by the influenza virus in mice. Gene Ther. 2001;8:1499-507.
107. Exner M, Minar E, Wagner O, Schillinger M. The role of heme oxygenase-1 promoter polymorphisms in human disease. Free Radic Biol Med. 2004;37:1097-104.

108. Mazur I, Wurzer WJ, Ehrhardt C, Pleschka S, Puthavathana P, Silberzahn T, Wolff T, Planz O, Ludwig S. Acetylsalicylic acid (ASA) blocks influenza virus propagation via its NF-kappaBinhibiting activity. Cell Microbiol. 2007;9:1683-94.

109. Liao CL, Lin YL, Wu BC, Tsao CH, Wang MC, Liu CI, Huang YL, Chen JH, Wang JP, Chen LK. Salicylates inhibit flavivirus replication independently of blocking nuclear factor kappa B activation. J Virol. 2001;75:7828-39.

110. Deng L, Zeng Q, Wang M, Cheng A, Jia R, Chen S, Zhu D, Liu M, Yang Q, Wu Y, Zhao X, Zhang S, Liu Y, Yu Y, Zhang L, Chen X. Suppression of NF- $\mathrm{KB}$ activity: a viral immune evasion mechanism. Viruses. 2018;10:409.

111. Wurzer WJ, Ehrhardt C, Pleschka S, Berberich-Siebelt F, Wolff T, Walczak H, Planz O, Ludwig S. NF-kappaB-dependent induction of tumor necrosis factor-related apoptosis-inducing ligand (TRAIL) and Fas/FasL is crucial for efficient influenza virus propagation. J Biol Chem. 2004;279:30931-7.

112. Schmitz ML, Kracht M, Saul VV. The intricate interplay between RNA viruses and NF-кB. Biochim Biophys Acta. 2014;1843:2754-64.

113. Toner P, McAuley DF, Shyamsundar M. Aspirin as a potential treatment in sepsis or acute respiratory distress syndrome. Crit Care. 2015;19:374.

114. Mankowski RT, Yende S, Angus DC. Long-term impact of sepsis on cardiovascular health. Intensive Care Med. 2019;45:78-81.

115. Panka BA, de Grooth HJ, Spoelstra-de Man AM, Looney MR, Tuinman PR. Prevention or treatment of Ards with aspirin: a review of preclinical models and meta-analysis of clinical studies. Shock. 2017;47:13-211.

116. Eisen DP, Moore EM, Leder K, Lockery J, McBryde ES, McNeil JJ, Pilcher D, Wolfe R, Woods RL. AspiriN To Inhibit SEPSIS (ANTISEPSIS) randomised controlled trial protocol. BMJ Open. 2017;7:e013636.

117. Falcone M, Russo A, Cangemi R, Farcomeni A, Calvieri C, Barillà F, Scarpellini MG, Bertazzoni G, Palange P, Taliani G, Venditti M, Violi F. Lower mortality rate in elderly patients with community-onset pneumonia on treatment with aspirin. J Am Heart Assoc. 2015;4:e001595.

118. Trauer J, Muhi S, McBryde ES, Al Harbi SA, Arabi YM, Boyle AJ, Cartin-Ceba R, Chen W, Chen YT, Falcone M, Gajic O, Godsell J, Gong MN, Kor D, Lösche W, McAuley DF, O’Neal HR Jr, Osthoff M, Otto GP, Sossdorf M, Tsai MJ, Valerio-Rojas JC, van der Poll T, Violi F, Ware L, Widmer AF, Wiewel MA, Winning J, Eisen DP. Quantifying the effects of prior acetyl-salicylic acid on sepsis-related deaths: an individual patient data meta-analysis using propensity matching. Crit Care Med. 2017;45:1871-9.

119. Ouyang Y, Wang Y, Liu B, Ma X, Ding R. Effects of antiplatelet therapy on the mortality rate of patients with sepsis: a metaanalysis. J Crit Care. 2019;50:162-8.

120. Ho-Tin-Noé B. Acetylsalicylic acid to fight thrombosis in sepsis. Blood. 2020;135:1195-6.

121. Leijte GP, Kiers D, van der Heijden W, Jansen A, Gerretsen J, Boerrigter V, Netea MG, Kox M, Pickkers P. Treatment with acetylsalicylic acid reverses endotoxin tolerance in humans in vivo: a randomized placebo-controlled study. Crit Care Med. 2019;47:508-16.

122. Derhaschnig U, Schweeger-Exeli I, Marsik C, Cardona F, Minuz P, Jilma B. Effects of aspirin and NO-aspirin (NCX 4016) on platelet function and coagulation in human endotoxemia. Platelets. 2010;21:320-8.

123. Hottz ED, Bozza FA, Bozza PT. Platelets in immune response to virus and immunopathology of viral infections. Front Med (Lausanne). 2018;5:121. 
124. O’Brien M, Montenont E, Hu L, Nardi MA, Valdes V, Merolla M, Gettenberg G, Cavanagh K, Aberg JA, Bhardwaj N, Berger JS. Aspirin attenuates platelet activation and immune activation in HIV-1-infected subjects on antiretroviral therapy: a pilot study. J Acquir Immune Defic Syndr. 2013;63:280-8.

125. Falcinelli E, Francisci D, Schiaroli E, Minuz P, Orsini S, Malincarne L, Sebastiano M, Mezzasoma AM, Pasticci MB, Guglielmini G, Baldelli F, Gresele P. Effect of aspirin treatment on abacavir-associated platelet hyperreactivity in HIV-infected patients. Int J Cardiol. 2018;263:118-24.

126. O'Brien MP, Hunt PW, Kitch DW, Klingman K, Stein JH, Funderburg NT, Berger JS, Tebas P, Clagett B, Moisi D, Utay NS, Aweeka F, Aberg JA. A randomized placebo controlled trial of aspirin effects on immune activation in chronically human immunodeficiency virus-infected adults on virologically suppressive antiretroviral therapy. Open Forum Infect Dis. 2017;4:ofw278.

127. Lajoie J, Birse K, Mwangi L, Chen Y, Cheruiyot J, Akolo M, Mungai J, Boily-Larouche G, Romas L, Mutch S, Kimani M, Oyugi J, Ho EA, Burgener A, Kimani J, Fowke KR. Using safe, affordable and accessible non-steroidal anti-inflammatory drugs to reduce the number of HIV target cells in the blood and at the female genital tract. J Int AIDS Soc. 2018;21:e25150.

128. Scheuch G, Canisius S, Nocker K, Hofmann T, Naumann R, Pleschka S, Ludwig S, Welte T, Planz O. Targeting intracellular signaling as an antiviral strategy: aerosolized LASAG for the treatment of influenza in hospitalized patients. Emerg Microbes Infect. 2018;7:21.

129. Kuo HC, Lo MH, Hsieh KS, Guo MM, Huang YH. Highdose aspirin is associated with anemia and does not confer benefit to disease outcomes in Kawasaki disease. PLoS ONE. 2015;10:e0144603.

130. Fries JF, Murtagh KN, Bennett M, Zatarain E, Lingala B, Bruce $B$. The rise and decline of nonsteroidal antiinflammatory drugassociated gastropathy in rheumatoid arthritis. Arthritis Rheum. 2004;50:2433-40.

131. Shanker A, Bhupathi V. Secondary prevention with antithrombotic therapies in stable ischemic heart disease patients: a review. Curr Cardiol Rep. 2019;21:56.

132. Rafaniello C, Ferrajolo C, Sullo MG, Sessa M, Sportiello L, Balzano A, Manguso F, Aiezza ML, Rossi F, Scarpignato C, Capuano A. Risk of gastrointestinal complications associated to NSAIDs, low-dose aspirin and their combinations: results of a pharmacovigilance reporting system. Pharmacol Res. 2016;104:108-14.

133. Li L, Geraghty OC, Mehta Z, Rothwell PM. Age-specific risks, severity, time course, and outcome of bleeding on long-term antiplatelet treatment after vascular events: a population-based cohort study. Lancet. 2017;390:490-9.
134. Chan FK, Kyaw M, Tanigawa T, Higuchi K, Fujimoto K, Cheong PK, Lee V, Kinoshita Y, Naito Y, Watanabe T, Ching JY, Lam K, Lo A, Chan H, Lui R, Tang RS, Sakata Y, Tse YK, Takeuchi T, Handa O, Nebiki H, Wu JC, Abe T, Mishiro T, Ng SC, Arakawa T. Similar efficacy of proton-pump inhibitors vs H2-receptor antagonists in reducing risk of upper gastrointestinal bleeding or ulcers in high-risk users of low-dose aspirin. Gastroenterology. 2017;152(105-110):e1.

135. Lanas A, McCarthy D, Voelker M, Brueckner A, Senn S, Baron JA. Short-term acetylsalicylic acid (aspirin) use for pain, fever, or colds-gastrointestinal adverse effects: a meta-analysis of randomized clinical trials. Drugs R D. 2011;11:277-88.

136. Chapman J, Arnold JK. Reye Syndrome. In: StatPearls. Treasure Island (FL): StatPearls Publishing; 2020.

137. Hongo T, Momoki N, Mae S, Nozaki S, Takahashi K, Fujiwara $\mathrm{T}$. A rare case of Reye's syndrome induced by influenza A virus with use of ibuprofen in an adult. Acute Med Surg. 2019;7:e457.

138. Magrum BG, Pickworth KK. Aspirin rechallenge in an adult patient previously diagnosed with Reye syndrome. Am J Health Syst Pharm. 2020;77:123-7.

139. Moore N, Le Parc JM, van Ganse E, Wall R, Schneid H, Cairns R. Tolerability of ibuprofen, aspirin and paracetamol for the treatment of cold and flu symptoms and sore throat pain. Int J Clin Pract. 2002;56:732-4.

140. Day M. Covid-19: ibuprofen should not be used for manging symptoms, say doctors and scientists. BMJ. 2020;368:m1086.

141. Voiriot G, Chalumeau M, Messika J, Basille D, Philippe B, Ricard J-D, Andrejak C, Jounieaux C, Sanchez O, Fartoukh M. Risks associated with the use of non-steroidal anti-inflammatory drugs during pneumonia. Rev Mal Respir. 2018;35:430-40.

142. FDA advises patients on use of non-steroidal anti-inflammatory drugs (NSAIDs) for COVID-19. FDA. 2020. https://www.fda. gov/drugs/drug-safety-and-availability/fda-advises-patients-usenon-steroidal-anti-inflammatory-drugs-nsaids-covid-19.

143. The use of non-steroidal anti-inflammatory drugs (NSAIDs) in patients with COVID-19. WHO. 2020. https://www.who.int/ publications/i/item/the-use-of-non-steroidal-anti-inflammato ry-drugs-(nsaids)-in-patients-with-covid-19.

144. EMA gives advice on the use of non-steroidal anti-inflammatories for COVID-19. EMA. 2020. https://www.ema.europa.eu/ en/news/ema-gives-advice-use-non-steroidal-anti-inflammato ries-covid-19.

145. Castagnoli R, Votto M, Licari A, Brambilla I, Bruno R, Perlini S, Rovida F, Baldanti F, Marseglia GM. Severe Acute Respiratory Syndrome Coronavirus 2 (SARS-CoV-2) infection in children and adolescents: a systematic review. JAMA Pediatr. 2020. https ://doi.org/10.1001/jamapediatrics.2020.1467. 